(2)

\title{
Aldehyde-induced insidious effects cannot be considered as a diatom defence mechanism against copepods
}

\author{
Kevin J. Flynn ${ }^{1, *}$, Xabier Irigoien ${ }^{2}$ \\ ${ }^{1}$ Institute of Environmental Sustainability, Swansea University, Swansea SA2 8PP, Wales, UK \\ ${ }^{2}$ AZTI-Tecnalia, Herrera Kaia, Portualdea z/g, 20110 Pasaia, Spain
}

\begin{abstract}
The last 2 decades have seen much controversy concerning the negative impacts that consumption of diatoms may have upon copepods. Because diatoms have traditionally been considered a major food item for copepods, this controversy has raised fundamental questions concerning our understanding of the marine food chain. The mode of operation of this negative impact is via socalled insidious effects on the survival of early-stage copepod progeny, caused for example by polyunsaturated aldehydes (PUA), with the mechanism proposed as a defence evolved by diatoms. Here the effects of diatoms on copepod reproduction rates are evaluated using a stoichiometric weight- or age-stage copepod model coupled with variable stoichiometric descriptions of prey. We show that, considering different combinations of copepod population age structure and diet composition (diatoms, non-diatoms, microzooplankton and copepods), the concept of an 'insidious' effect of diatom consumption upon copepods cannot be sustained as a defence mechanism, as it does not confer any advantage to the diatoms. While metabolites that deter grazing can be advantageous, slowly killing a predator (via the death of juvenile copepods) responsible for consuming competitor primary producers, and also consuming another predator (microzooplankton), is not advantageous to the diatoms. Indeed it is shown to be counterproductive on occasion. While PUA (or compounds that act in a similar fashion) have the potential to adversely affect copepod production, alternative explanations for their production need consideration. Such alternatives include the potential impact of PUA against microzooplankton, or simply that PUA represent secondary metabolites of no evolutionary selective advantage.
\end{abstract}

KEY WORDS: Defence metabolite - Trophic dynamics - Trophic cascade - Copepod · Diatom • Herbivore

\section{INTRODUCTION}

During the last 2 decades a number of experiments have shown that some diatom diets tend to decrease the egg hatching rate of copepods (see Paffenhöfer et al. 2005). The effect of this decrease has controversially been hypothesised to reflect a defence mechanism against grazing developed by diatoms (Jónasdóttir et al. 1998, Irigoien et al. 2002, Pohnert et al. 2002, 2007, Frost 2005). However, as the mechanism does not directly decrease diatom mortality, the effect was suggested as 'insidious'. The 'insidious effect' argument was originally proposed by Ban et al. (1997), and has appeared in a subsequent series of articles, including some in high impact journals (Miralto et al. 1999, Ianora et al. 2004). The original 'insidious effect' argument runs as follows: 'The cells of many diatoms contain an ... inhibitory compound that blocks embryogenesis when ingested by the females. This 'inhibition' may represent a defence mechanism by diatoms against grazing by copepod offspring, thereby prolonging diatoms blooms' (Ban et al. 1997, p. 291). Further research identified polyunsaturated aldehydes (PUA) as a candidate inhibitory compound, with production triggered by mechanical damage of the 
diatom cell upon consumption by the copepod (Pohnert 2000). More recently, further compounds have been proposed (Fontana et al. 2007), although there is great variability in presence of these compounds in different phyla (Ceballos \& Ianora 2003, Adolph et al. 2004, Casotti et al. 2005, Wichard et al. 2005). The term PUA-positive (PUA+) will be used to describe the presence of any compound that elicits a delayed, age-stage related (upon early-stage naupli) impact upon copepods consuming diatoms.

We will argue here that inhibition of egg viability cannot be a selective force for the evolution of a grazing defence by diatoms against copepods, operating under a 'for the good of the species' argument when considering the species as a selection unit. That is, the mechanism does not increment the number of the gene copies or the success of the individual diatom offspring; at most it may affect the number of individuals of the species. Critically, the diatom cells, and hence the genes responsible for coding the production of the toxic aldehyde precursors, have to be destroyed (ingested) to have an effect on the hatching rates of the predator. It is exactly because such traits resulting in an advantage for (or improving the success of) the offspring will not be passed on to the next generation (i.e. there is a lack of heritability) that 'for the good of the species' arguments were strongly criticised long ago in evolutionary biology and population genetics (Maynard Smith 1964, Williams 1966). Nowadays, the main selection units are considered to be genes or individuals (Dawkins 1976, Ridley 2003). Although some debate remains about group selection (Ridley 2003, Borrello 2005), the general opinion is that, in nature, group selection is rarely likely to override individual selection (Ridley 2003). Furthermore, diatoms cannot be considered as a group in the context of such a debate, as there is no temporal continuity of the group.

It could be argued that all the cells of the same diatom clone should be considered, from an evolutionary standpoint, as a single individual or genome. In this instance we would be speaking of kin selection (Hamilton 1964), defined by Maynard Smith (1964) as the 'evolution of characteristics which favor the survival of close relatives of the affected individual', instead of group selection. In that circumstance a benefit at the genome level would be justified and comparable to the insidious effects observed in the relations between terrestrial plants and insects (Miralto et al. 1999, Stamp 2003). However, even if all the diatoms in a bloom were part of a very limited number of clones (but see Rynearson \& Armbrust 2005, Rynearson et al. 2006, both of which show high clonal diversity in blooms), the comparison is not valid because there is no spatial homogeneity and no temporal continuity in the relation between predator and prey. In terrestrial plants, the spatial coherence is obvious and the probability of different cells of the same plant being attacked by the same predator high. Furthermore, insects are often plant-specific predators and hosts, and therefore the whole plant (gene copies and individual) will benefit if the ingestion of part of the plant inhibits the reproduction of the predator. In pelagic systems, in contrast, diatoms are unicellular or short chains of individual cells that, even during blooms, are dispersed, mixed and often consumed together with other taxa. Dietary diversity rather than specificity is typical of pelagic systems and copepods prey on a large range of nano- and microplanktonic cells in addition to diatoms. Consequently, the sacrifice of the individual diatom cell benefits at some later time not only its own clone, but also those of competitors (other phytoplankton) and predators (ciliates and heterotrophic dinoflagellates). Actually, copepod predation pressure upon ciliate microzooplankton is generally higher than on phytoplankton (Calbet \& Saiz 2005), and microzooplankton are likely to be the main predators of phytoplankton (Calbet \& Landry 2004, Calbet 2008), including diatoms (Leising et al. 2005a).

Additionally, it is necessary to consider the time scales from ingestion to a potential decrease of the grazing impact. This is in the order of $1 \mathrm{wk}$ for egg production, hatching and development to naupliar feeding stages in the case of fast-growing copepod species such as Acartia sp., and up to 1 yr for species such as Calanus glacialis and C. hyperboreus. Compared to such time scales, phytoplankton division times are in the order of 10 s of hours to days, while changes in species and genus dominance are in the order of 1 to $2 \mathrm{~d}$, with blooms rarely lasting more than $1 \mathrm{wk}$. Considering that the insidious effect may also benefit competitor phytoplankton and predators, and that most likely the effect peaks when the so-called insidious clone is no longer dominant in the water column, the argument would be better termed as a 'for the good of the microplankton' rather than a 'for the good for the species' one. The temporal and spatial scales of the 'transgenerational plant-herbivore interaction' (Ianora et al. 2004) do not coincide and, in consequence, the probability of the copepod offspring consuming a cell of the same clone that induced hatching inhibition is lower than that of consuming a competitor or predator of that clone. If the production of the defence is concentrated in the latter phases of the bloom (Ribalet et al. 2007), then the mismatch between toxin production and benefit for the toxin-producing clone increases further. Under the encounter and mixing time scales involved here, the phytoplankton blooms cannot be considered as 'viscous' populations in the sense used by Hamilton (1964) (populations with low rates or short ranges of dispersal) where kin selection could act. Considering 
Hamilton's rule for the increase in gene frequency in the population through kin selection $(\mathrm{rB}>\mathrm{C}$, where $\mathrm{r}=$ genetic relatedness, $\mathrm{B}=$ additional reproductive success of the recipients of the altruistic act and $\mathrm{C}=$ reproductive cost to the individual performing the act), for the insidious effect of diatoms, the B may be expected to be close to zero.

To illustrate the above arguments, that $B \approx 0$, here we analyse the effects of timing (match and mismatch between copepod age structure and prey availability) and interactions between predators and competitors with and without inclusion of a PUA-like insidious defence mechanism. We use models for this analysis, describing the growth of 2 phytoplankton groups (diatom and nondiatom), and grazing groups microzooplankton and copepod. This type of simulation provides a method to assess the potential for evolutionary effects of prey on consumers, providing an a priori test of the hypothesis that there is an effective defence mechanism in operation. The copepod model contains a full stoichiometric description of food assimilation and is thus capable of simulating the implications of poor quality feed on copepod reproduction and so enabling a resolution of the PUA versus poor-diet issue (Jónasdóttir et al. 1998, Jones et al. 2002, Jones \& Flynn 2005). It also includes a new prey selectivity function that allows deselection of noxious prey (Mitra \& Flynn 2006a). This ingestionassimilation model is coupled with an age-stage submodel describing the growth of the copepod population, allowing an explicit consideration of PUA interactions upon reproductive success. The implications of feeding on different diets in a dynamic scenario were assessed, including different predator-prey combinations and with different copepod population age structures. We show that even including a deleterious effect due to consumption of diatoms (both nutrient-poor and/or PUA-producing) to copepod production, and assuming all diatoms to be of the same clone, there is no evidence that PUA provides protection against grazing for diatoms, and evidence for the contrary state due to trophic interactions that enhance diatom death.

\section{METHODS}

The model describes 2 primary producers (diatom and non-diatom) and 2 zooplankton groups (microzooplankton and copepod); the non-diatom fraction is hereafter termed 'flagellate'. The physiological basis of the zooplankton models followed that described by Mitra (2006) for a C,N biomass description, with a coupled description of ingestion and stoichiometric-linked growth, excretion and voiding of waste material.

The microzooplankton in the model (maximum growth rate, $\mu_{\max }=0.6 \mathrm{~d}^{-1}$; maximum assimilation effi- ciency, $\mathrm{AE}=0.8$ ) ingested with equal biomass-based affinity diatom, flagellate, microzooplankton (i.e. intraguild predation and cannibalism is enabled) and (with a lower affinity) microfaecal material. This model used the same structure and values of constants as that employed by Mitra \& Flynn (2006b), employing the prey selectivity function of Mitra \& Flynn (2006a).

The copepod model had the same food processing structure as that of the microzooplankton, although with a lower C-specific $\mu_{\max }\left(0.4 \mathrm{~d}^{-1}\right)$ and a lower maximum AE (0.4). The stoichiometric model thus automatically degraded the copepod growth rate as food $\mathrm{N}$ :C declined; net copepod growth is not possible on food of low N:C (Jones et al. 2002, Jones \& Flynn 2005). This copepod biomass model was coupled to a weight/ age-stage submodel, in keeping with the experimental data in Rey et al. (2001), Rey-Rassat et al. (2002) and Carlotti et al. (2007); advancement to the next development stage required a minimum age and also a minimum weight. Others have used similar approaches to formulate detailed models of copepod growth dynamics (e.g. Stegert et al. 2007). At 0 h of each simulation day, each generation aged $1 \mathrm{~d}$. Four stages were identified. Eggs and non-feeding nauplii (EN stage) occupied ages $0-6$ d. Feeding nauplii occupied ages over this and for sizes less than $0.01 \mathrm{mg} \mathrm{C}$, copepodites were between 0.01 and $0.05 \mathrm{mg} \mathrm{C}_{\text {, with adults over }}$ this range. The biomass growth of adults was directed to reproduction, which was converted to egg numbers with age zero at $0 \mathrm{~h}$ on each simulation day. Depending on nutritional intake (poor stoichiometric value prey provide less nutrient for egg production, just as they provide less nutrient for somatic growth (see Mitra 2006), a maximum yield of 50 new eggs per adult per day could be attained. The EN stage had spontaneous death rates of $0.1 \mathrm{~d}^{-1}$, and copepodites and adults of $0.05 \mathrm{~d}^{-1}$; the maximum age was $30 \mathrm{~d}$. Copepods ingested with equal biomass-based affinity diatoms, flagellates, microzooplankton and larger detrital material. The copepodite and adult copepod stages could also consume eggs and non-feeding nauplii stages (i.e. displaying cannibalism). The preyselectivity function of Mitra \& Flynn (2006a) was used.

The phytoplankton model, using a normalised quota construction (Flynn 2003), described N- and Si-limited growth of diatoms $\left(\mu_{\max }=1 \mathrm{~d}^{-1}\right)$ and N-limited growth of flagellate populations $\left(\mu_{\max }=0.5 \mathrm{~d}^{-1}\right)$, with variable (Si:)N:C on consumption of $\mathrm{NO}_{3}{ }^{-}, \mathrm{NH}_{4}{ }^{+}$and $\mathrm{Si}$. The diatoms could be made PUA-positive (PUA+); the implication of this is that consumption of diatom cells by adult copepods, relative to the amount required to satiate them, was used to raise the spontaneous death rate of the EN stage of their progeny by up to $0.6 \mathrm{~d}^{-1}$. There was no link made between this event and diatom nutrient status (cf. Ribalet et al. 2007, Vidoudez \& Pohnert 
2008); accordingly, the model may overestimate the impact of PUA, as it is assumed here that consumption of even healthy PUA+ diatoms may be deleterious. In addition, the flagellate population could be made noxious, such that as their nutrient status declined they were progressively rejected as food items by both microzooplankton and copepods (methods described in, and as implemented by, Mitra \& Flynn 2006a,b).

The ecosystem was configured with a mixing rate of $0.01 \mathrm{~d}^{-1}$ (typical of mid Atlantic spring-summer; Lochte et al. 1993), which introduced $\mathrm{NO}_{3}{ }^{-}$and $\mathrm{Si}$ and washed out all nutrients and plankton in the mixed layer other than copepodites and adult copepods (which were considered to be able to swim across the mixed layer). Nutrient concentrations below the mixed layer were $0.5 \mu \mathrm{M}$ ammonium, $10 \mu \mathrm{M}$ nitrate and $10 \mu \mathrm{M}$ silicate, and were used as initial concentrations. Regenerated $\mathrm{NH}_{4}{ }^{+}$from zooplankton activity was available for use by the phytoplankton. The depth of the mixed layer was set at $20 \mathrm{~m}$. Increasing biomass within the water resulted in self-shading of primary production. Simulations were run for $60 \mathrm{~d}$; beyond this (and indeed potentially within this period) external physical forcings could be expected to so overturn biological processes that projections beyond this period would become increasingly unsafe.

The models were run with 4 phytoplankton scenarios: (1) non-noxious phytoplankton (both diatoms and flagellates), (2) toxic diatoms and non-noxious flagellates, (3) non-toxic diatoms and noxious flagellates, or (4) toxic diatom and noxious flagellate populations. Toxic diatoms were PUA+, affecting copepods only, while noxious flagellates (their noxious state developing only during nitrogen stress; see Mitra \& Flynn 2006b) were avoided by both microzooplankton and copepods. The default scenarios contained start biomasses of $20 \mathrm{mg} \mathrm{C} \mathrm{m}^{-3}$ each of diatoms and flagellates, and $10 \mathrm{mg} \mathrm{C} \mathrm{m}^{-3}$ each of microzooplankton and copepods. Three alternate copepod population scenarios were considered, each of different age-structured populations. These alternate copepod population structures (each with a total of $10 \mathrm{mg} \mathrm{C} \mathrm{m}^{-3}$ ) were 'mixed' (2500 eggs, 600 nauplii, 300 copepodites, 118 adults $\mathrm{m}^{-3}$ ), 'young' (10 000 early feeding nauplii $\mathrm{m}^{-3}$ ) or 'old' (200 adults $\mathrm{m}^{-3}$ ).

Models were constructed and run using Powersim Constructor 2.5 (N-5100). The Powersim model code is available as MEPS Supplementary Material (Appendix 1 at www.int-res.com/articles/suppl/m377p079_app/); the model is available from K. J. Flynn. The additional reproductive success of the recipients of the altruistic act (parameter B in Hamilton's rule) was estimated as the percentage difference of cumulated biomass during the run relative to the control simulations in which neither phytoplankton displayed noxious characteristics.

\section{RESULTS}

When neither phytoplankton displayed any noxious potential, the faster growing diatoms dominated over the flagellates, and microzooplankton were grazed out by the copepods (Fig. 1a,c,e). The initial copepod age structure had a strong impact on system dynamics (Fig. 1). Although inclusion of PUA+ diatoms could have a considerable impact upon copepod growth dynamics (except when starting with early developmental stage copepods; Fig. 1c,d), there was no evidence that the diatoms benefited from this interaction; if anything the converse was evident (Fig. 1a,b,e,f).

Although there could be (depending on copepod age structure) clear signs of an effect on copepod population growth due to consumption of PUA+ diatoms, the major impact was to shift the timing of the copepod production cycle; by the end of the simulation period the total copepod biomass was not necessarily lower, and could even be enhanced (Fig. 1a,b). This reflects a trophic cascade of predator-prey and nutrient regenerative interactions throughout the system. The impact upon the copepod population structure is shown in Fig. 2. The timing of the consumption of PUA+ diatoms relative to the copepod age structure was critical in this regard. The greatest effect on the copepods was seen when the diatom population was grazed by late stage (old) copepods (Fig. 2e,f), but even here the diatom population was not enhanced (Fig. 1e,f).

With PUA+ diatoms, there is no enhancement of diatom population growth; in fact, there is evidence to the contrary (Fig. A1b) (Figs. A1 to A3 are available in Appendix 2 at www.int-res.com/articles/suppl/m377 p079_app/). In contrast to the impact of PUA production by diatoms upon ecosystem dynamics (i.e. as seen in PUA+ versus non-PUA+ diatom configurations), the production of a grazing deterrence by nutrientstressed flagellates that affected both microzooplankton and copepod grazing could be of clear benefit to these phytoplankton (Fig. A1c). With flagellates that become noxious when nutrient-stressed, flagellates rather than diatoms come to dominate (Fig. A1c). A combination of PUA+ diatoms and noxious flagellates (Fig. A1d) again showed that the diatoms did not benefit from producing a slow-acting toxin against only one of their predators (copepods, but not microzooplankton), while the flagellate grazing deterrence against both their predators was of value.

A series of additional scenarios, including a change in water mixing rates (thus slowing the rate of nutrientlimitation of phytoplankton growth, Fig. A2b), lower initial phytoplankton biomass (thus increasing the likelihood of grazing control, Fig. A2c), eutrophication (thus promoting top-down predator control rather than bottom-up nutrient control of primary production, 


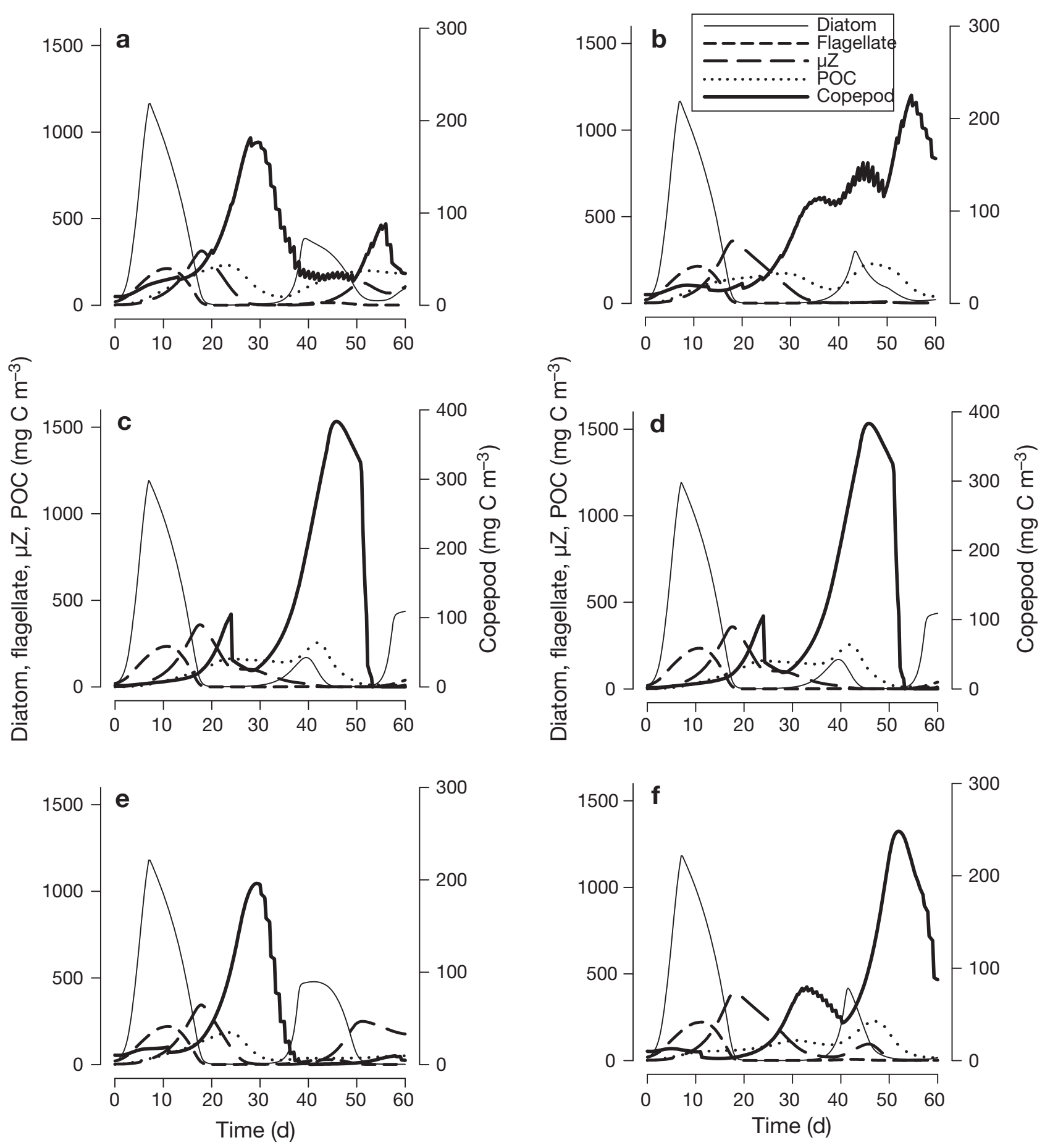

Fig. 1. Changes in population structure during simulated planktonic predator-prey interactions between populations of diatoms, flagellates, microzooplankton $(\mu \mathrm{Z})$ and copepods. Also shown is the total dead particulate organic $\mathrm{C}$ (POC). $\mu \mathrm{Z}$ consume diatoms, flagellates, POC and other $\mu \mathrm{Z}$; copepods consume all others, including adults eating early developmental stages of their own kind. Three copepod population scenarios are shown: $(\mathrm{a}, \mathrm{b})$ mixed; $(\mathrm{c}, \mathrm{d})$ young; and $(\mathrm{e}, \mathrm{f})$ old. Left-hand panels show the control situation, with non-toxic diatoms (not PUA+). Right-hand panels show the situation with diatoms which are PUA+, liberating polyunsaturated aldehydes (PUA) when grazed by copepods; PUA adversely affects survival of juvenile copepods. Nutrients became limiting for phytoplankton growth from Day 10 onwards for at least the next $20 \mathrm{~d}$ 

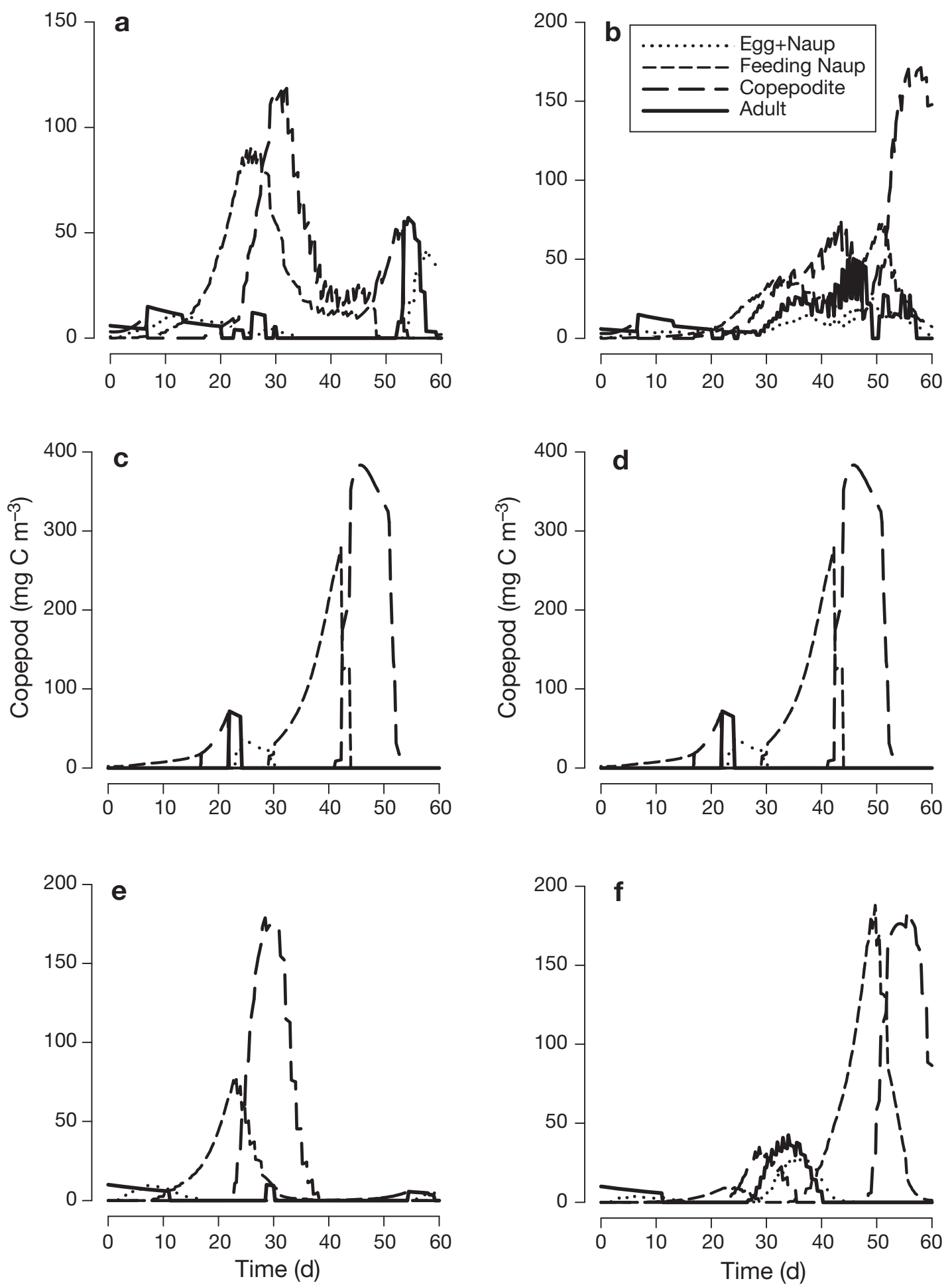

Fig. 2. Detail of the stage-structured copepod biomass population shown in the respective components (a-f) of Fig. 1. Shown are fractions containing eggs and non-feeding naupliar stages (Egg + Naup), feeding naupili, copepodites and adults. Biomass growth of adult stages is directed towards production of new eggs. Consumption of PUA+ diatoms by adults promotes death of eggs and non-feeding nauplii (Egg + Naup) 
Fig. A2d), copepod-only grazing (thus removing the role of microzooplankton as intermediate grazers and as food for copepods, Fig. A2e), a combination of eutrophication with no microzooplankton (Fig. A2f) and diatom-only primary production (thus elevating the role of diatoms as prey for copepods, Fig. A2g) showed strongly contrasting dynamics. However, in none of these scenarios was any benefit clearly demonstrated for diatoms being PUA+; being PUA+ does not enhance diatom population growth but temporally displaces copepod production.

The ineffectiveness of being PUA+ upon diatom success is summarised in Fig. 3. In comparison with the neutral or negative effect of being PUA+, the effect of becoming noxious during nutrient stress for the flagellates was clearly advantageous (note the $y$-axis scale in Fig. 3). A more complete analysis is shown in Fig. A3; being PUA+ had no sustained positive benefit under any scenario tested, and usually the consequence was negative; positive differences, where they occurred, were small. In all instances being PUA+ was disadvantageous to the diatoms (negative differences). In contrast, becoming noxious during nutrient stress was clearly advantageous to the flagellates (large positive differences for noxious flagellate configurations) (Fig. A3a). In the eutrophic and no microzooplankton scenario, the presence of PUA+ diatoms was more advantageous to the flagellates than to the diatoms (Fig. A3b).

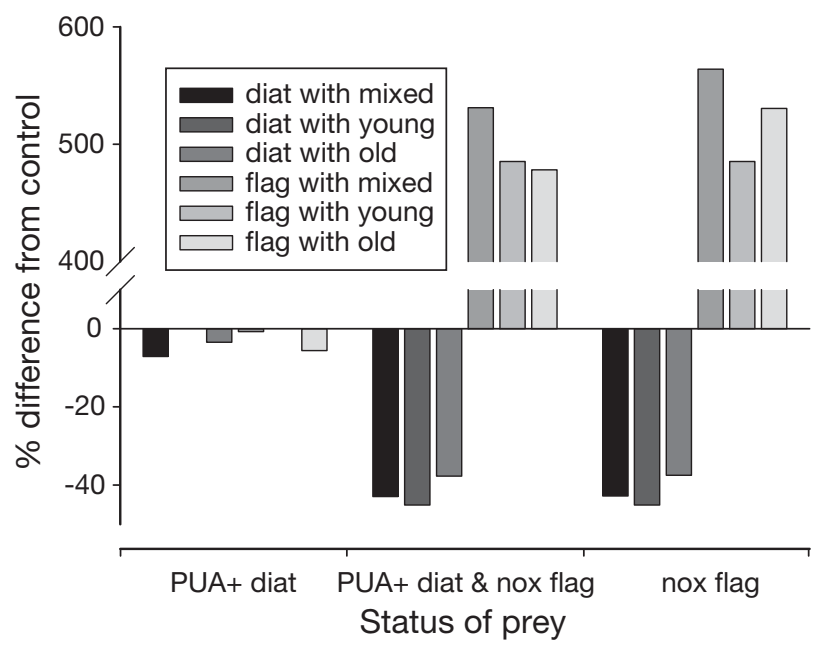

Fig. 3. Difference in algal production (cumulative C-fixed) at Day 60 between a control configuration (containing nonPUA+ diatoms and non-noxious flagellates) and prey configurations in which diatoms were PUA+ and/or flagellates could become noxious (nox). The models described growth of diatoms (diat) and flagellates (flag) in systems initially containing mixed, young or old copepod populations. A negative difference indicates a situation where production was lower than in the control

\section{DISCUSSION}

The hypothesis that PUA-related (or PUA-associated, or similar) delayed deaths of copepods represent a defence for diatoms carries with it the null hypothesis that the event does not represent exhibition of an insidious defence. That is, to accept the hypothesis we need to reject the null hypothesis to obtain evidence that it does represent a plausible defence mechanism. The main approach hitherto has been a posteriori, making the tacit assumption that any and all traits are adaptive (Sibly \& Calow 1986), and hence that because the consumption of diatoms by copepods can result in a failure in copepod reproduction there must be some advantage to the diatoms. Applying an a priori approach to this complex problem we find no evidence to support the hypothesis. From our results, which included a range of contrasting scenarios, we conclude that despite the potential impacts of PUA liberation by diatoms on copepod population structure, the timing of events (matching of predators with bloom dynamics, age structure of the copepods, etc.) and the behaviour of other components of the system (e.g. microzooplankton or the noxious status of flagellates) have as much, if not more, capacity to affect diatom and copepod growth than does the liberation of PUA upon copepod reproduction. Indeed, the simulations indicate that killing copepods may be expected to be typically deleterious for diatoms, because in the absence of such high copepod numbers the grazing activity of microzooplankton is enhanced. This result is consistent with expectations (Calbet \& Landry 2004, Calbet \& Saiz 2005, Leising et al. 2005a).

An analysis by Flynn (2008) of the potential value of alternate predation mitigation strategies for phytoplankton identified the development of grazing deterrents (such as described here by the noxious flagellate configuration) as being most effective. The initial assessment of the value of delayed-action deathcausing mechanisms suggested that these were as likely to benefit competitor phytoplankton as the producing species (Flynn 2008). The advance here is the explicit description of the age structure of the predator (copepods), and our simulations clearly show the important differential impact of PUA on copepods depending on the age structure at the time of encounter (Figs. $1 \& 2$ ). The impact upon an older population, which is so dependent upon the successful production of a new cohort before its own death, was most sensitive; here there was an effective loss of a generation of copepods (Fig. 2e,f). It does not matter whether the impact of the 'insidious effect' is upon egg production or against the viability of eggs that are produced. The net result is the same: for a given effort by the adults there is a loss in reproduction to the next 
generation. In contrast, the impact upon a young population could be insignificant (Fig. 2c,d). Any impact of consumption of PUA+ diatoms by copepods in the field may only occur briefly and be of importance only under certain conditions (Pierson et al. 2005), notably when only diatoms are present as food for the otherwise prey-selective copepods. Pierson et al. (2007) also argued that, in general, predation upon copepods (topdown effect) is likely to be more important for the loss of a specific generation than diatom-induced (i.e. bottom-up) mortality.

An additional approach that we have used is to invoke Hamilton's (1964) rule. From our simulations Hamilton's test ( $\mathrm{rB}>\mathrm{C}$ ) fails because $\mathrm{B}$, the additional reproductive success of the recipients of the altruistic act (i.e. the diatoms), is often actually negative (Fig. 3). Whether the cost of synthesis of the toxin precursors (C) is significant or not for the growth of the diatoms is of no consequence to this interpretation; if the value of $\mathrm{C}$ is significant, this only makes the test fail more convincingly. As it is we do not know if there are specific genes coding for the process, or whether it is a consequence of random metabolite and enzyme mixing during diatom cell consumption. If it is not transmissible (involving genetics) then it could not be properly described as a defence mechanism.

Our model projection showing that a poor nutritional diet will not enable good copepod growth is supported by experimental work (Jones \& Flynn 2005); thus, copepod growth on low-nutrient status prey (Fig. A2e) is at least as deleterious as the impact of consumption of PUA+ diatoms (Jónasdóttir \& Kiørboe 1996). Copepod reproductive success can be highest in summer when, although plankton abundance is typically lower, the mixed composition gives a good quality, highly varied diet. There is evidence of selective feeding by copepods when presented with different prey (Jones et al. 2002, Leising et al. 2005a), which would further enhance production when presented with mixed food items, as poor quality prey are more likely to be rejected. At other times, although hatching success may be suboptimal due to diatom ingestion (Halsband-Lenk et al. 2005), because of the overall relief of food limitation in diatom-dominated blooms the total success of copepods is nonetheless enhanced; it is better to eat poor food than to starve. While in winter algal growth may be dominated by diatoms and is associated with low copepod reproduction (Miralto et al. 2003), low temperatures are likely to be at least as important in limiting copepod growth. Previous modelling studies (Mazzocchi et al. 2006, Moll \& Stegert 2007) have shown the importance of diet, temperature and mortality as important determinants in copepod production. From all of these results we conclude that it cannot be held that consumption of PUA+ diatoms by copepods will always be deleterious (Miralto et al. 1999), and that other factors are at least as important and would counter or mask any direct affect of PUA.

If the impact of diatom consumption upon copepods is so variable, could being PUA+ be expected to be an advantageous selective trait for these primary producers? Diatom growth can be so rapid that copepods simply cannot constrain it; this would itself argue against the value of a slow acting insidious toxin defence (Ianora et al. 2004). That the model output suggests that being PUA+ can actually be detrimental to diatom populations only strengthens the arguments (see 'Introduction') against an advantageous role for an insidious defence. Microzooplankton grazing represents the dominant control on phytoplankton activity (Strom 2002, Tillmann 2004), often including diatoms (Leising et al. 2005a), and one would thus expect that natural selection would operate on phytoplankton displaying defensive measures against these organisms (Irigoien et al. 2005). Even if one argued that the microzooplankton impact upon diatoms is relatively minor and that there is a clear delineation between microzooplankton and copepod grazed communities (Sommer et al. 2005), microzooplankton are still responsible for the regeneration of nutrients used by diatoms and the removal of competitor phytoplankton, and, importantly, also present an alternative good quality food source for copepods. In our simulations the consumption of microzooplankton could be critically important for maintaining an optimal stoichiometric food value of the total diet for copepods (Fig. A2e).

If copepod abundance is lowered, then microzooplankton activity can increase, as the latter's growth is less restrained by copepod predator activity (Flynn 2008). There are suggestions that such trophic cascade effects occur in nature (Leising et al. 2005b) and that copepods may exert their greatest effect on phytoplankton through their grazing on microzooplankton (Nejstgaard et al. 1997). Experimental evidence (Vadstein et al. 2004) also suggests that the balance between copepods and microzooplankton can play a pivotal role in controlling bloom dynamics, especially as microzooplankton may be favoured prey items for copepods (Vadstein et al. 2004). All of these points are borne out in our simulations, with microzooplankton clearly playing an important role in trophic dynamics, as predators of phytoplankton, prey for copepods and as nutrient regenerators (Fig. A2e).

Alternatively, aldehydes may act as a feeding deterrent with a secondary effect such as hatching inhibition. This is similar to what has already been observed in toxic dinoflagellates (e.g. Selander et al. 2006, but cf. Avery et al. 2008) and would explain why aldehyde- 
producing diatom strains have a stronger hatching inhibitory effect, as the lower ingestion would enhance the nutritional deficiency effect on copepods with restricted diets. Indeed, the model shows for flagellates that feeding-deterrent effects (as contrasted with a lethal effect) may have a real defensive value (Fig. 3), therefore eliminating the 'for the good of the species' criticism to the proposed mechanism. Whether or not aldehydes are a feeding deterrent for copepods or ciliates (see below) is key to understanding their effect. While some works suggest that PUA do represent a feeding deterrent for copepods (Jüttner 2005, Leising et al. 2005c), in other instances diatom size seems to be more important for selection (e.g. Dutz et al. 2008). PUA do not appear to be a deterrent for freshwater Daphnia (Carotenuto \& Lampert 2004). However, there is a wide range of effects of noxious phytoplankton upon copepods, and studies may be confounded by investigations using mixed or single-species diets (Colin \& Dam 2003).

If PUA were a feeding deterrent, although not comparable to the insidious effect of toxins in terrestrial plants, the effect could be considered comparable to another interesting mechanism in terrestrial ecology where plants communicate to other plants that are being attacked through release and detection of volatile compounds. In diatoms it has been shown that production of aldehydes by a damaged cell could act as a signal in surrounding cells (Vardi et al. 2006). This may appear logical in terms of defence specificity because this 'alert' would only be useful for the species or strains able to produce aldehydes in the surrounding environment of the damaged cell. There would also be a high probability of such cells being of the same clone, especially if the diatoms formed part of a chain or colony. However, the fundamental problem remains: the temporal and spatial diffusion scales of such signals are likely to be orders of magnitude longer (many days/weeks for the effect of PUA to feed back through the system to decrease grazing rates) and smaller (the chemical signal is only perceived by neighbouring cells; see Fig. 4 in Vardi et al. 2006) than needed to stimulate a response to a copepod ingesting a number of cells or sweeping up a small volume creating a feeding current.

While these aspects require further investigation, an alternative and perhaps more plausible hypothesis would be for aldehydes to represent not a defence developed against copepods but against microzooplankton, or indeed as allelopaths against other phytoplankton. However, such mechanisms are only effectual at high concentrations of the producing organism else diffusion most likely dilutes the signal too rapidly (Lewis 1986). Flynn (2008) argues that allelopaths may only be of value for organisms that establish large (harmful algal) blooms, helping the continuation of such blooms rather than their establishment. Such a defence would make most sense against the microzooplanktonic predators which represent major consumers of phytoplankton (Calbet \& Landry 2004, Calbet 2008), and even of diatoms during blooms (Leising et al. 2005a), and that also feed and grow in time and spatial scales comparable to that of the diatoms. To our knowledge aldehydes have not been tested as feeding deterrent for microzooplankton, but DMSP and dinoflagellate toxins have been shown to act as deterrents against ciliates (Colin \& Dam 2003, Strom et al. 2003, Kubanek et al. 2007).

Another potential explanation for the effect of PUA remains. PUA are catabolites of fatty acid degradation produced when the diatom is injured or in bad condition (Pohnert 2000). It might be simply that PUA are secondary metabolites without any functional defence role, which may coincidentally have a deleterious effect on copepods when provided at high concentrations (a situation that is not common in the field). In that sense they would not play a role in the arms race between diatoms and their predators and would not be subject to evolutionary pressure. This may explain why there is such variability in the susceptibility of copepods to PUA and of diatoms to be PUA+ (Taylor et al. 2007, Wichard et al. 2005). The most recent works on the subject (Dutz et al. 2008, Koski et al. 2008, Vidoudez \& Pohnert 2008, Wichard et al. 2008) also point to a complex interaction, with no clear evidence for the defence hypothesis.

While the present study shows the importance of trophic cascades, stoichiometric value of the diet, nutrient regeneration within the system and matching of primary production with copepod age structure upon secondary production, we find no evidence at all to support the insidious defence hypothesis. While ingestion of PUA+ diatoms can have an impact in the copepod population, it cannot be a major factor explaining year-to-year variation in copepod production. Neither can it help explain the success of diatoms. Our conclusion is clear: an insidious defence associated with PUA production is a misnomer as it cannot confer an advantage to diatoms, and indeed could be considered as counterproductive. For further consideration of the hypothesis that PUA-like substances do indeed represent a defence mechanism, additional rounds of experimental and modelling research are required. In addition, the potential effect of PUA as feeding deterrents, in particular for microzooplankton, remains unexplored.

Acknowledgements. K.J.F. thanks R. Harris for his help in configuring the model description of the copepods. 


\section{LITERATURE CITED}

Adolph S, Bach S, Blondel M, Cueff A and others (2004) Cytotoxicity of diatom-derived oxylipins in organisms belonging to different phyla. J Exp Mar Biol Ecol 207: 2935-2946

Avery DE, Altland KJK, Dam HG (2008) Sex-related differential mortality of a marine copepod exposed to a toxic dinoflagellate. Limnol Oceanogr 53:2627-2635

Ban SH, Burns C, Castel J, Chaudron Y and others (1997) The paradox of diatom-copepod interactions. Mar Ecol Prog Ser 157:287-293

Borrello ME (2005) The rise, fall and resurrection of group selection. Endeavour 29:43-47

Calbet A (2008) The trophic roles of microzooplankton in marine systems. ICES J Mar Sci 65:325-331

Calbet A, Landry M (2004) Phytoplankton growth, microzooplankton grazing, and carbon cycling in marine systems. Limnol Oceanogr 49:51-57

Calbet A, Saiz E (2005) The ciliate-copepod link in marine ecosystems. Aquat Microb Ecol 38:157-167

Carlotti F, Bonnet D, Halsband-Lenk C (2007) Development and growth rates of Centropages typicus. Prog Oceanogr 72:164-194

Carotenuto Y, Lampert W (2004) Ingestion and incorporation of freshwater diatoms by Daphnia pulicaria: Do morphology and oxylipin production matter? J Plankton Res 26:563-569

> Casotti R, Mazza S, Brunet C, Vantrepotte V, Ianora A, Miralto A (2005) Growth inhibition and toxicity of the diatom aldehyde 2-trans, 4-trans-decadienal on Thalassiosira weissflogii (Bacillariophyceae). J Phycol 41:7-20

Ceballos S, Ianora A (2003) Different diatoms induce contrasting effects on the reproductive success of the copepod Temora stylifera. J Exp Mar Biol Ecol 294:189-202

Colin SP, Dam HG (2003) Effects of the toxic dinoflagellate Alexandrium fundyense on the copepod Acartia hudsonica: a test of the mechanisms that reduce ingestion rates. Mar Ecol Prog Ser 248:55-65

Dawkins R (1976) The selfish gene. Oxford University Press, New York

Dutz J, Koski M, Jonasdottir SH (2008) Copepod reproduction is unaffected by diatom aldehydes or lipid composition. Limnol Oceanogr 53:225-235

Flynn KJ (2003) Modelling multi-nutrient interactions in phytoplankton; balancing simplicity and realism. Prog Oceanogr 56:249-279

Flynn KJ (2008) Attack is not the best form of defense: lessons from harmful algal bloom dynamics. Harmful Algae 8: 129-139

Fontana A, Cutignano AGA, Romano G, Lamari N and others (2007) LOX-induced lipid peroxidation mechanism responsible for the detrimental effect of marine diatoms on zooplankton grazers. ChemBioChem 8:1810-1818

Frost BW (2005) Diatom blooms and copepod responses: Paradigm or paradox? Prog Oceanogr 67:283-285

> Halsband-Lenk C, Pierson JJ, Leising AW (2005) Reproduction of Pseudocalanus newmani (Copepoda: Calanoida) is deleteriously affected by diatom blooms: a field study. Prog Oceanogr 67:332-348

Hamilton WD (1964) The genetical evolution of social behaviour. J Theor Biol 7:1-16

Ianora A, Turner JT, Esposito F, Carotenuto Y and others (2004) Copepod egg production and hatching success is reduced by maternal diets of a non-neurotoxic strain of the dinoflagellate Alexandrium tamarense. Mar Ecol Prog Ser 280:199-210
Irigoien X, Harris RP, Verheye HM, Joly P and others (2002) Copepod hatching success in marine ecosystems with high diatom concentrations. Nature 419:387-389

Irigoien X, Flynn KJ, Harris RP (2005) Phytoplankton blooms: A 'loophole' in microzooplankton grazing impact? J Plankton Res 27:313-321

> Jónasdóttir SH, Kiørboe T (1996) Copepod recruitment and food composition: Do diatoms affect hatching success? Mar Biol 125:743-750

Jónasdóttir SH, Kiørboe T, Tang KW, St. John M, Visser AW, Saiz E, Dam HG (1998) Role of diatoms in copepod production: good, harmless or toxic? Mar Ecol Prog Ser 172: 305-308

Jones RH, Flynn KJ (2005) Nutritional status and diet composition affect the value of diatoms as copepod prey. Science 307:1457-1459

Jones RH, Flynn KJ, Anderson TR (2002) Effect of food quality on carbon and nitrogen growth efficiency in the copepod Acartia tonsa. Mar Ecol Prog Ser 235:147-156

Jüttner F (2005) Evidence that polyunsaturated aldehydes of diatoms are repellents for pelagic crustacean grazers. Aquat Ecol 39:271-282

- Koski M, Wichard T, Jonasdottir SH (2008) 'Good' and 'bad' diatoms: development, growth and juvenile mortality of the copepod Temora longicornis on diatom diets. Mar Biol 154:719-734

Kubanek J, Snell TW, Pirkle C (2007) Chemical defense of the red tide dinoflagellate Karenia brevis against rotifer grazing. Limnol Oceanogr 52:1026-1035

Leising AW, Horner R, Pierson AW, Postel J, Halsband-Lenk C (2005a) The balance between microzooplankton grazing and phytoplankton growth in a highly productive estuarine fjord. Prog Oceanogr 67:366-383

- Leising AW, Pierson JJ, Halsband-Lenk C, Horner R, Postel J (2005b) Copepod grazing during spring blooms: Can Pseudocalanus newmani induce trophic cascades? Prog Oceanogr 67:406-421

> Leising AW, Pierson JJ, Halsband-Lenk C, Horner R, Postel J (2005c) Copepod grazing during spring blooms: Does Calanus pacificus avoid harmful diatoms? Prog Oceanogr 67:384-405

Lewis WM Jr (1986) Evolutionary interpretations of allelochemical interactions in phytoplankton algae. Am Nat 127:184-194

- Lochte K, Ducklow HW, Fasham MJR, Stienen C (1993) Plankton succession and carbon cycling at $47^{\circ} \mathrm{N} 20^{\circ} \mathrm{W}$ during the JGOFS North Atlantic Bloom Experiment. Deep Sea Res II 40:91-114

Maynard Smith J (1964) Group selection and kin selection. Nature 201:1145-1147

Mazzocchi MG, Buffoni G, Carotenuto Y, Pasquali S, d'Alcala MR (2006) Effects of food conditions on the development of the population of Temora stylifera: a modeling approach. J Mar Syst 62:71-84

Miralto A, Barone G, Romano G, Poulet SA and others (1999) The insidious effect of diatoms on copepod reproduction. Nature 402:173-176

Miralto A, Guglielmo L, Zagami G, Buttino I, Granata A, Ianora A (2003) Inhibition of population growth in the copepods Acartia clausi and Calanus helgolandicus during diatom blooms. Mar Ecol Prog Ser 254:253-268

- Mitra A (2006) A multi-nutrient model for the description of stoichiometric modulation of predation in micro- and mesozooplankton. J Plankton Res 28:597-611

Mitra A, Flynn KJ (2006a) Accounting for variation in prey selectivity by zooplankton. Ecol Model 199:82-92

Mitra A, Flynn KJ (2006b) Promotion of harmful algal blooms 
by zooplankton predatory activity. Biol Lett 2:194-197

Moll A, Stegert C (2007) Modelling Pseudocalanus elongatus stage-structured population dynamics embedded in a water column ecosystem model for the northern North Sea. J Mar Syst 64:35-46

Nejstgaard JC, Gismervik I, Solberg PT (1997) Feeding and reproduction by Calanus finmarchicus, and microzooplankton grazing during mesocosm blooms of diatoms and the coccolithophore Emiliania huxleyi. Mar Ecol Prog Ser 147:197-217

Paffenhöfer GA, Ianora A, Miralto A, Turner JT and others (2005) Colloquium on diatom-copepod interactions. Mar Ecol Prog Ser 286:293-305

Pierson JJ, Halsband-Lenk C, Leising AW (2005) Reproductive success of Calanus pacificus during diatom blooms in Dabob Bay, Washington. Prog Oceanogr 67:314-331

Pierson JJ, Frost BW, Leising AW (2007) The lost generation of Calanus pacificus: Is the diatom effect responsible? Limnol Oceanogr 52:2089-2098

Pohnert G (2000) Wound-activated chemical defence in unicellular planktonic algae. Angew Chem Int Ed 39: 4352-4354

Pohnert G, Lumineau O, Cueff A, Adolph S, Cordevant C, Lange M, Poulet S (2002) Are volatile unsaturated aldehydes from diatoms the main line of chemical defence against copepods? Mar Ecol Prog Ser 245:33-45

Pohnert G, Steinke M, Tollrian R (2007) Chemical cues, defence metabolites and the shaping of pelagic interspecific interactions. Trends Ecol Evol 22:198-204

Rey C, Harris R, Irigoien X, Head R, Carlotti F (2001) Influence of algal diet on growth and ingestion of Calanus helgolandicus nauplii. Mar Ecol Prog Ser 216:151-165

Rey-Rassat C, Irigoien X, Harris R, Head R, Carlotti F (2002) Growth and development of Calanus helgolandicus reared in the laboratory. Mar Ecol Prog Ser 238:125-138

Ribalet F, Wichard T, Pohnert G, Ianora A, Miralto A, Casotti $\mathrm{R}$ (2007) Age and nutrient limitation enhance polyunsaturated aldehyde production in marine diatoms. Phytochemistry 68:2059-2067

Ridley M (2003) Evolution. Blackwell Science, Cambridge

Rynearson TA, Armbrust EV (2005) Maintenance of clonal diversity during a spring bloom of the centric diatom Ditylum brightwellii. Mol Ecol 14:1631-1640

Rynearson TA, Newton JA, Armbrust EV (2006) Spring bloom development, genetic variation, and population succession in the planktonic diatom Ditylum brightwellii. Limnol Oceanogr 51:1249-1261

Selander E, Thor P, Toth G, Pavia H (2006) Copepods induce paralytic shellfish toxin production in marine dinoflagellates. Proc R Soc Lond Biol Sci 273:1673-1680

Sibly RM, Calow P (1986) Physiological ecology of animals.

Editorial responsibility: Andrew Brierley,

St. Andrews, UK
Blackwell Scientific Publications, Oxford

Sommer U, Hansen T, Blum O, Holzner N, Vadstein O, Stibor $\mathrm{H}$ (2005) Copepod and microzooplankton grazing in mesocosms fertilised with different $\mathrm{Si} \mathrm{N}$ ratios: no overlap between food spectra and Si:N influence on zooplankton trophic level. Oecologia 142:274-283

> Stamp N (2003) Out of the quagmire of plant defense hypotheses. Q Rev Biol 78:23-55

> Stegert C, Kreus M, Carlotti F, Moll A (2007) Parameterisation of a zooplankton population model for Pseudocalanus elongatus using stage durations from laboratory experiments. Ecol Model 206:213-230

> Strom S (2002) Novel interactions between phytoplankton and microzooplankton: their influence on the coupling between growth and grazing rates in the sea. Hydrobiologia 480:41-54

Strom S, Wolfe G, Holmes J, Stecher H, Shimeneck C, Lambert S, Moreno E (2003) Chemical defense in the microplankton I: feeding and growth rates of the heterotrophic protests on the DMS-producing phytoplankter Emiliania huxleyi. Limnol Oceanogr 48:217-229

- Taylor RL, Caldwell GS, Dunstan HJ, Bentley MG (2007) Short-term impacts of polyunsaturated aldehyde-producing diatoms on the harpacticoid copepod, Tisbe holothuriae. J Exp Mar Biol Ecol 341:60-69

Tillmann U (2004) Interactions between planktonic microalgae and protozoan grazers. J Eukaryot Microbiol 51:156-168

Vadstein O, Stibor H, Lippert B, Løseth K, Roederer W, SundtHansen L, Olsen Y (2004) Moderate increase in the biomass of omnivorous copepods may ease grazing control of planktonic algae. Mar Ecol Prog Ser 270:199-207

> Vardi A, Formiggini F, Casotti R, De Martino A, Ribalet F, Miralto A, Bowler C (2006) A stress surveillance system based on calcium and nitric oxide in marine diatoms. PLoS Biol 4:411-419

Vidoudez C, Pohnert G (2008) Growth phase-specific release of polyunsaturated aldehydes by the diatom Skeletonema marinoi. J Plankton Res 30:1305-1313

- Wichard T, Poulet SA, Halsband-Lenk C, Albaina A, Harris RP, Liu DL, Pohnert G (2005) Survey of the chemical defence potential of marine and freshwater diatoms: screening of fifty species for $\alpha, \beta, \gamma, \delta$-unsaturated aldehydes. J Chem Ecol 31:949-958

Wichard T, Poulet SA, Boulesteix AL, Ledoux JB, Lebreton B, Marchetti J, Pohnert G (2008) Influence of diatoms on copepod reproduction. II. Uncorrelated effects of diatomderived $\alpha, \beta, \gamma, \delta$-unsaturated aldehydes and polyunsaturated fatty acids on Calanus helgolandicus in the field. Prog Oceanogr 77:30-44

Williams GC (1966) Adaptation and natural selection. Princeton University Press, Princeton, NJ

Submitted: April 23, 2008; Accepted: November 27, 2008 Proofs received from author(s): February 20, 2009 